\title{
Linguocognitive Conflict of Digital and Pre-Digital Thinking in Online Educational Discourse During the Pandemic: Social Danger or a New Challenge?
}

\author{
Irina S. Karabulatova*a, , Ainash K. Aipova*c, \\ Saad Masood Butt ${ }^{\mathrm{d}}$ and Stefania Amiridoue \\ 'Peoples' Friendship University of Russia \\ Moscow, Russian Federation \\ ${ }^{b}$ Moscow Institute of Physics and Technology \\ Moscow, Russian Federation \\ 'Toraighyrov Pavlodar State University \\ Pavlodar, Kazakhstan \\ 'Institute of Electrical and Electronics Engineers \\ Townsville, Australia \\ ${ }^{e}$ Democritis University \\ Komotini, Greece
}

Received 01.09.2021, received in revised form 13.09.2021, accepted 14.09.2021

\begin{abstract}
The authors analyze the problems of online educational discourse in the context of the linguocognitive conflict of the «pre-digital» and «digital generations» in connection with mediated communication during the COVID-19 pandemic. Today, society has actualized hidden socio-cultural conflicts that have increased the disharmonious influence on the implementation of online educational discourse in a situation of prolonged self-isolation and lockdowns. The authors distinguish a separate subtype of educational discourse-online educational discourse, it is the result of an interactive process of interaction of subjects in an indirect educational space of an online format, within which intercultural, interpersonal communication, a diverse verbal-paraverbal exchange of information using digital means of communication is carried out. At the same time, the possibilities of the language of the participants of educational communication are evaluated in the context of expressing their communicative intentions. The situation of the pandemic has updated the features in the decoding of information in the «digital generation». The specifics of the speech-thinking activity of the «digital generation» are a pseudo-psychopatholinguistic phenomenon, which requires new approaches to online educational discourse in the formation of competencies. The new situation requires the allocation of other parameters for the psychodiagnostics of norm and pathology in the work of the language and brain. Humanity is looking for compromises for the full-fledged formation of various competencies based on language, using online educational dialogue as optimal in terms of survival during a pandemic. The specifics of the language behavior of the «digital generation» reflect a different type
\end{abstract}

\footnotetext{
(C) Siberian Federal University. All rights reserved

* Corresponding author E-mail address: radogost2000@mail.ru,pgu@tou.edu.kz ORCID: 0000-0002-4228-3235(Karabulatova); 0000-0002-8428-8018 (Aipova); 0000-0002-6252-9116 (Butt)
} 
of thinking than that of the representatives of the «pre-digital generation». The article reflects the results of an international study on the formation of students ' communicative competence using online educational discourse during the COVID-19 pandemic.

Keywords: language behavior, a pseudopathopsycholinguistic phenomenon, communicative competence, «digital generation», Russians, Australians, Greeks, Kazakhs, online-educational discourse.

This paper was financially supported by the Ministry of Education and Science of the Russian Federation through the program to improve the competitiveness of the Peoples' Friendship University of Russia (PFUR University, RUDN-university) among the world's leading research and education centers.

Research area: psycholinguistics.

Citation: Karabulatova, I.S., Aipova, A.K., Butt, S.M., Amiridou, S. (2021). Linguocognitive conflict of digital and pre-digital thinking in online educational discourse during the pandemic: social danger or a new challenge? J. Sib. Fed. Univ. Humanit. soc. sci., 14(10), 1517-1537. DOI: 10.17516/1997-1370-0836

\title{
Лингвокогнитивный конфликт цифрового и доцифрового мышления в онлайн-учебном дискурсе в период пандемии: социальная опасность или новый вызов?
}

\author{
И.С. Карабулатова ${ }^{a, 6}$, А.К. Аиповав, \\ С.М.Буттг, С. Амиридуд \\ ${ }^{a}$ Российский университет дружбы народов \\ Российская Федерачия, Москва \\ ${ }^{6}$ Московский физико-технический институт (Национальный университет) \\ Российская Федерачия, Москва \\ ${ }^{8}$ Павлодарский государственный университет им. С. Торайгырова \\ Павлодар, Казахстан \\ 'Прикладной институт инженеров электротехники и электроники \\ Таунсвилл, Австралия \\ г Фракийский университет им. Демокрита \\ Комотини, Греция
}

Аннотация. Авторы анализируют проблемы онлайн-учебного дискурса в условиях лингвокогнитивного конфликта «доцифрового» и «цифрового поколений» в связи с опосредованной коммуникацией в период пандемии COVID-19. Сегодня общество актуализировало скрытые социокультурные конфликты, которые усилили дисгармоничное влияние на реализацию онлайн-учебного дискурса в ситуации длительной самоизоляции и локдаунов. Авторы выделяют отдельный подтип учебного дискурса - онлайн-учебный дискурс, он есть результат интерактивного процесса взаимодействия субъектов в опосредованном учебном пространстве онлайн-формата, в рамках которого осуществляется межкультурная, межличностная коммуникация, 
разнообразный вербально-паравербальный обмен информацией с использованием цифровых средств коммуникации. Одномоментно оцениваются возможности языка участников учебной коммуникации в контексте выражения их коммуникативных намерений. Ситуация пандемии актуализировала особенности в декодировании информации у «цифрового поколения». Специфика речемыслительной деятельности «цифрового поколения» есть псевдопсихопатолингвистический феномен, что требует новых подходов к онлайн-учебному дискурсу при формировании компетенций. Новая ситуация требует выделения других параметров для психодиагностики нормы и патологии в работе языка и мозга. Человечество ищет компромиссы для полноценного формирования разнообразных компетенций на основе языка, используя онлайн-учебный диалог как оптимальный в условиях выживания в период пандемии. Специфика языкового поведения «цифрового поколения» отражает иной тип мышления, чем у представителей «доцифрового поколения». В статье отражены результаты международного исследования по формированию коммуникативной компетенции у студентов с помощью онлайн-учебного дискурса в период пандемии COVID-19.

Ключевые слова: языковое поведение, псевдопатопсихолингвистический феномен, коммуникативная компетенция, «цифровое поколение», Россия, Греция, Казахстан, Австралия, онлайн-учебный дискурс.

Исследование было поддержано Министерством образования и науки Российской Федерации по программе повышения конкурентоспособности Университета Дружбы народов России (РУДН) среди ведущих мировых исследовательских и образовательных центров.

Научная специальность 10.02.00 - языкознание.

\section{Introduction}

Modern globalization, pandemic restrictions and intensification of migration processes have forced the world society to plunge into the problems of digital humanities, intercultural communication, ethnopsycholinguistics, ethnopedagogy, linguo-regional studies, linguodidactics, linguoculturology (Zamaletdinov et al., 2014). However, the situation of the COVID-19 pandemic (Druzhinin, Molchanova, 2021) has redistributed the emphasis in the educational and academic discourse (Karasik, 2016; Dronov, 2020), making the online learning format as the only possible, although controversial in methodological terms (Ukrainets, 2020). At the same time, we cannot but note the fact that the educational discourse itself in its online form is also undergoing a transformation in the selection of material, in its presentation and in communication, which is due to a greater extent to the transformation in the speech-thinking processes and cognitive operations of the language personality of the «digital generation».
The new situation in the global educational space has revealed the unpreparedness of the education system for the new realities and conditions of operating with information by «digital natives», revealing gaps in the linguistic and didactic aspects of psycholinguistics in the context of understanding the processes of interaction between language and thinking, both in the context of encoding and decoding information in natural language and in the language of neural networks.

Traditionally, the educational discourse focuses the audience's attention on the formation of ethnic and socio-cultural identity among representatives of the state-forming ethnic group. This idea began to be promoted through an ethnooriented educational discourse in the postSoviet world (Aipova et al., 2021; Belbotayev, Bulanbayeva, 2007; Petukh, 2004; Shabambayeva et al., 2021), as a guarantee of the geopolitical stability of the state. At the same time, political scientists and sociologists emphasize that these countries are experiencing a power- 
ful migration burden and the consequences of ethnic trauma due to a sense of infringement of national dignity and ignoring the efforts of the Soviet Union in terms of the formation of national elites in the Soviet republics (Ryazantsev et al., 2015; Osipov et al., 2016), without taking into account the transformations that occurred under the influence of the strategies of forming a person of communism. This inevitably led to cognitive distortions of various forms of identity (Lin, et al., 2021).

This attitude could not but affect the approaches to the educational discourse of intercultural communication in the post-Soviet and post-socialist space. However, in our opinion, it reflects an outdated paradigm of linguodidactics, focused primarily on the expert teaching staff of the generation of the pre-digital era with a characteristic linear type of thinking.

At the same time, we draw attention to the existing positive experience of forming the content of the educational discourse of intercultural communication in countries with a stable migration load and a higher level of proficiency in English as the language of modern science (Greece, Australia), despite the changes that occur with the speech-thinking processes of students when studying in an online format.

The choice of countries for this study (Australia, Greece, Kazakhstan, Russia) is due to historical ties and changes that occur in the process of language acquisition in the context of globalization and migration during the formation of intercultural communicative competence in universities based on the material of Russian, English, Greek and Kazakh languages.

Modern science pays priority attention to the study of English as the language of modern intercultural communication and scientific interaction, so the popularity of teaching English in different countries is significant, but the level of English proficiency shows a big difference across countries. Thus, in 2019, according to the English Proficiency Index, Kazakhstan ranked 93rd out of 100 in terms of the level of English language proficiency of the population (Informburo.kz, 5.11.2019, electronic resource), having advanced to the 92nd place by the end of 2020. Greece occupies the 21st position in the same study, Russia-41st place (Ranking of countries by the level of English language proficiency, 2020, Electronic resource).

A special situation relates to Australia. On the one hand, the country was founded as a British colony with the involvement of aborigines. On the other hand, the mass filling of the country at the expense of assorted criminals and their family members transformed the originally British version of the English language, forming the Australian English language with an abundance of embedded jargon and the specifics of pronunciation (Agapova, Gorbunova, 2014; Baker Sidney, 1945).

The colonial aspirations of Great Britain (Sagimbayev, 2017) could not but affect the promotion of British English, which served and continues to serve as a socio-political marker, since native speakers of British English are positioned as carriers of an elite linguistic culture as opposed to uneducated social strata of the population both in the British Empire itself and abroad. Thus, the very possession of the British version of the English language becomes one of the conditions for information and psychological strategies of Great Britain in hybrid geopolitical wars (Tagiltseva, 2018). We see the same demonstration of the superiority of the British English language in global geopolitics in relation to the American English language (it is built on the principle of accessibility and comprehensibility to everyone) and to the Australian English language (it was built based on the principles of the argot of the thieves " world). In this regard, we must consider these initial data when diving into the educational discourse based on the English language, since they also demonstrate the imbalance of attitude to the norms of intercultural communication in different English-speaking countries and countries where the English language is being comprehensively promoted.

Russian language online educational discourse also reveals difficulties, since the selection of material for studying Russian as a foreign language has not yet been regulated at the state level for migrants from the post-Soviet world and non-CIS countries (Khudorenko, 2020). As a result, we see a narrowing of the area of use of the Russian language. Thus, in 
Kazakhstan, the priorities in the language policy have changed in the direction of strengthening the position of the Kazakh language, strengthening the English language, promoting the Chinese language with the weakening of the role of the Russian language due to the 4-language promoted and implemented in the country (Sultan, Sabirova, 2018).

Therefore, we can talk about social stigmatization in education (Pashkovsky, 2017) during the period of pandemic restrictions due to:

1) subjective perception of social isolation;

2) the priority of online educational discourse due to the pandemic;

3) students' experiences of their own ethno-linguistic and confessional affiliation;

4) transformations of speech-thinking cognitive abilities in the conditions of changed learning formats;

5) experiencing the consequences of COVID-19 for health, etc.

Additional pressure is exerted by the information policy of countries on mandatory vaccination of the population, which also acquires a mythologized aura of conspiracy, transforming the attitude to the educational process in the conditions of a pandemic (Galle et al., 2021). Sociologists emphasize that social stigmatization, regardless of the quality of the assessment of the perception of an event, phenomenon, or fact, actualizes the state of discomfort in individuals, forming appropriate behavioral and communicative-verbal stereotypes, which only increases the distance between a person and society (Pashkovsky, 2017). The natural increased interest in the topic of the pandemic also stigmatizes all the processes of society's life activity that are somehow related to COVID-19, including in the educational discourse.

In addition, particular issues of local geopolitics are superimposed on the global problems of contrasting generations of the predigital and digital eras, which changes not only the standard of education, but also the very understanding of the speech-thinking processes of modern man. At the same time, the speed of information acquisition and the level of perception of digital reality can also become a social stigma.
It should be noted that the dominance of the presentation of information through digital communication increases interest in foreign languages, linguoculturology, intercultural communication and linguistic and country studies.

In this regard, the analyzed countries are of interest from the point of view of mastering the communicative norms and standards of intercultural communication, taking into account the ethnic and socio-cultural specifics of the country. For example, Australia and Greece are known for their democratic foundations. Australia is a country of migrants with a very mobile mentality and a desire for equality, which is manifested in linguistic and pedagogical trends and speech research (Edwards, 2018). Russia, Kazakhstan, and Greece are quite conservative in terms of the stability of traditions and the degree of proficiency in English as the language of international communication (Galskova, Gez, 2009; Solontsova, 2015).

However, all the analyzed countries demonstrate a steady interest and an increase in demand for specialists who speak English, which is also provoked by the dominant position of the English language in the field of scientific knowledge, and above all, technical scientific knowledge.

Australian experts are concerned about the decline in the growth of educational migrants in the country due to the pandemic, emphasizing the importance of immersion in the realities of linguistic culture beyond online learning (Hurley, 2020). When analyzing the situation in Greek universities, we consider the specifics of the communicative competence of Greek students aimed at learning Russian, since Russia was and remains in the sphere of Greek interests due to its historical and confessional community, close socio-economic and cultural ties (Amiridou, 2017; DavtyanIokamidi, 2015). The educational discourse of the Russian language in the Greek audience has its own long history and traditions, which are based on the oral linear model of teaching in direct contact "teacher + student», which has developed since antiquity (Polychronidou, 2013), which transformed the format of communication in online educational discourse. At 
the same time, there is an interesting trend in Kazakhstan in connection with the Kazakhization of the Russian-speaking part of the Kazakh society (Petuch, 2004; Belbotaev, Bulanbayeva, 2009), where there is a hybridization of linear and nonlinear learning models. The inclusion of Australia in our study is since Australia was previously part of Siberia and the Far East, which was described in the prerevolutionary media (Kanevskaya, 2007; Govor, 2018). At one time, N. N. Miklukho-Maklay made every effort to arouse research interest in Australia in Russian society, having influenced the language and communication of aborigines (Martynov, Martynova, Valeev, 2018). The openness and activity of migration made the nonlinear learning model preferable.

Thus, the four countries taken for analysis were conditioned by mutual geopolitical interests, but at the same time they became an illustration of different approaches to immersion in the educational discourse during the pandemic.

All four countries are of great interest as states focused on migration processes and intercultural communication, realizing the geopolitical aspirations of their countries in the context. We believe that the formation of professional competencies of future foreign language teachers in Russia, Australia, Kazakhstan and Greece goes through the prism of «ideological phantoms» of these countries (Beregovaya, Karlova, 2020) and cognitive distortions caused by extralinguistic factors of geopolitics, followed by changes in the behavioral and communicative matrix that fixes changes in the language picture of the world (Vassilenko et al., 2018; Ruan, Karabulatova, 2021; Karabulatova, Lagutkina et al., 2021).

This transformation of the behavioral and communicative matrix became the reason for the psychodiagnostic search for cognitive and other deviations in the "digital generation» (Semke, Bohan, 2008; Grekova, 2019).

Social restrictions due to the COVID-19 pandemic, the transformation of the rhythm of society's life, the dominance of the electronicdigital format of learning and communication have changed the requirements for the communicative matrix in the online educational discourse. However, the online educational discourse in connection with the COVID-19 pandemic has changed the paradigm of «student - teacher» communication to the «student - Internet - teacher» format, indicating the competitiveness of digital learning tools and pointing out the importance of ethnosocio-cultural and linguistic-pedagogical components in the process of teaching foreign languages (Karabulatova et al., 2021; Krotik, Morhun, 2021; Shehi et al., 2020; Ukrainets, 2020).

The variety and randomness of massed information using techniques of psycholinguistic influence on the audience makes teachers carefully consider both the ways of presenting information and its content in modern online educational discourse. A special place in this regard is occupied by the mythologization of the coronavirus in different countries, which affects both the communication itself and the nature of classes (Karabulatova, Lagutkina, Amiridou, 2021). This makes us turn to the historical experience of fighting epidemics and social rehabilitation after their completion (Marinenko et al., 2019; Kattsina, Karabulatova, 2019; Ruan, Karabulatova, 2021). However, in addition to these difficult conditions, we are faced with the problem of the peculiarities of the thinking of the «digital generation», which must be considered when online learning.

\section{Materials and methods}

The materials for the analysis were obtained by comparing the communicative activities of students in universities in Russia, Greece, Australia, and Kazakhstan during the implementation of an online educational discourse during the pandemic.

Communicative activity in the online educational discourse was regulated using case methods recommended by the authors of various textbooks (Arakin, 2016; Petuch, 2004). The online educational discourse allows us to detail the results obtained during online classes in Russian, Greek, Australian and Kazakh audiences, on the assimilation of ethno-cultural information that significantly differs from the culture of students' ethno-identity.

At the Thracian Democritus University (Komotini, Greece), the sample consisted of 
80 Greek students studying Russian. At the Toraighyrov Kazakhstan University (Pavlodar, Kazakhstan), the sample consisted of 156 people studying the Kazakh language. The sample of students studying English as a non-native language in Australia was 144 people. The control group of students studying at the RUDN was 20 people. The team of authors conducted an empirical study in 2019-2021. We conducted a secondary comparative analysis of the data obtained by other researchers on the specifics of educational communication activities and ways of assimilating the materials of online educational discourse during the pandemic and beyond. Online educational discourse allows you to quickly fix the mistakes made by students, revealing hidden gaps in students' knowledge when learning another language.

The modern paradigm of the educational language discourse is aimed at forming a transcultural identity of a global type among students (Ebzeeva et al., 2018), thanks to which the norms and socio-cultural stereotypes of a foreign language are assimilated along with the ethno-socio-cultural complex of the rules of the native linguoculture. In this regard, we took as a hypothesis the statement about the specificity of the formation of linguistic and cultural consciousness among students-future teachers in the field of linguistics. At the same time, we took two important points: 1) the active use of integrative methods contributes to the harmonious development of multiculturalism and transcultural language personality among recipient students; 2) the methods of the linguoculturological approach are a priority in the online educational discourse for the formation of a harmonious transcultural language personality.

In this regard, we conducted ascertaining and forming experiments to measure changes in the ethno-linguistic behavior of students during the formation of linguistic and cultural communicative competencies. However, these experiments also revealed new results in changing cognitive functions in thinking among representatives of the pre-digital and digital eras.

In addition, we focused on the use of such methods as traditional theoretical analysis of scientific and methodological literature with a generalization of modern innovative methodological approaches to the development of linguistic and cultural communicative competence of students in the aspect of discursive practices, linguistic modeling of secondary language personality, discourse analysis, the principle of integrated subject-language learning and the principle of continuous learning in the context of the COVID-19 coronavirus pandemic.

Work on communication studies, ethnological pedagogy, linguistics, language teaching, psycholinguistics laid the theoretical foundation of the research work (Aipova, etc., 2021; Gervilla, Garcia, 2020; Grekova, 2019; Mattheoudakis, Alexiou, 2009; Petuch, 2004).

The focus was on the analysis of studies related to the development of a multicultural educational environment in the modern world linguodidactics (Peng and $\mathrm{Wu}, 2016$; Rutskaya et al., 2021, etc.), especially considered works aimed at analyzing the development of language and communication abilities in conditions of isolation, stress, migration, etc. (Semke, Bohan, 2008).

\section{Results}

The results of the online educational discourse of the pandemic period (Agranovich et al., 2021; Ukrainets, 2020) will still require their scientific understanding in many aspects, revealing new facets of the implementation of educational discourse, which made it possible to designate this type of discourse as an «inverted» educational resource (Barkhatova et al., 2021).

An international team of authors conducted observations of student groups who are on distance learning to understand and refine the algorithm of learning another language in the conditions of the transition of a linear strategy of educational discourse to a nonlinear strategy of online educational discourse. Our observations have allowed us to understand new universals in the thinking of the modern digital generation, which will illustrate the difference between the generations of the pre-digital and digital era. 
As a result, the online educational discourse makes it necessary to compress the educational material to microportions due to the use of additional digital educational formats of mobile applications, social networks and other new training services that use fast switching and multitasking of mental operations of a modern native speaker (Karabulatova, Ldokova, Bankozhitenko, Lazareva, 2021).

Today, psychologists talk about «digital aborigines», «digital generation» (Grekova, 2019; Alyokhin, Grekova, 2018), for whom it is necessary to develop new standards of psychodiagnostics, linguodidactics to differentiate them from the so-called pathopsycholinguistic (Pashkovsky, Piotrovskaya, Piotrovsky, 2015) and pseudo-pathopsycholinguistical phenomena of thinking in a digital environment (Grekova, 2019).

The complexity of the online educational discourse is since the teacher, as the author and creator of the course, is uncomfortable because of the difference in the assessments of the surrounding world with his students, who are representatives of digital reality and process incoming information differently.

As a rule, teachers using the traditional linear model of educational discourse find that the overwhelming number of students belong either to the ignoring part of the audience or to the passive part of the group, which is interpreted as an excessively negative influence of the Internet (Zaretskaya, 2017). The results of the observation are shown in Fig. 1.

The modern generation of teachers belongs to the generation of the pre-digital era, whose thinking is based on the generally accepted hierarchy of generic characteristics on the foundation of anthropocentrism (Kholodnaya, 2002). Indeed, the reference criterion for decoding information in the perception of the pre-digital generation in the humanities is an anthropocentric approach, in which the existing traditional «hierarchy of generic / specific features with a certain measure of the concrete/ abstract, like a filter, was superimposed on all concepts/phenomena of the surrounding world» (Grekova, 2019: 35).

However, modern students who are representatives of the» digital generation " perceive this approach as boring, not interesting, and not effective, because they otherwise build a system of selecting the significant and insignificant when evaluating incoming information. Based on this, they demonstrate passive and ignoring participation in the online educational discourse.

The observation method allowed us to establish that during classroom classes only $30 \%$ of students actively participate in the educational process, while $50 \%$ of students demonstrate passivity in communication. These students listen to the teacher, but are silent, slowly perform the tasks that are offered to them, and $20 \%$ ignore and behave distantly. Groups of passives and ignoring students do not just go about their business during the lesson, but treat classes as a hypertext space under the influence of the organizational structure of the Network (this includes: listening to the lecturer, correspondence with other gadgets, simultaneous reading and viewing materials on the topic of

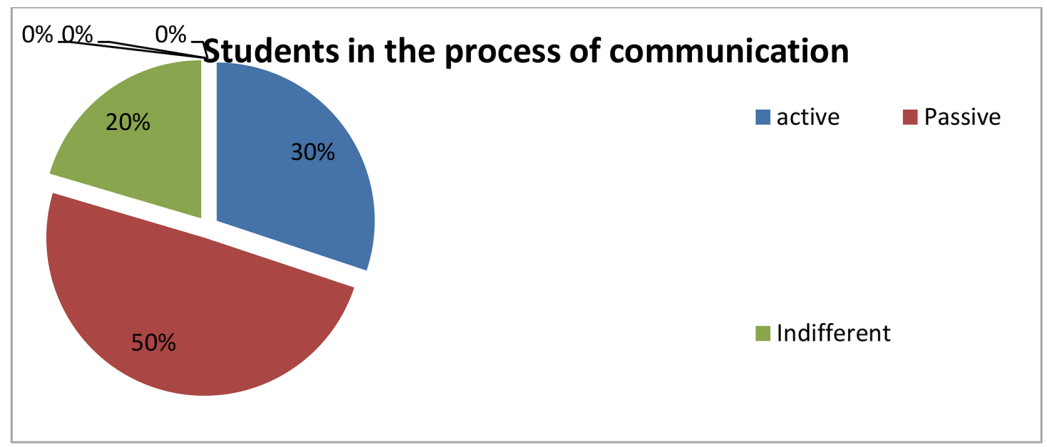

Fig. 1. Cumulative results of the method of monitoring the process of communication of students 
the lesson and/or on the topic of another academic discipline, parallel preparation of a presentation for an educational/ scientific report, etc.).

At the same time, teachers evaluate the cognitive abilities of «digital students», focusing on the departure from the usual standard of response in the direction of strengthening pseudopsychopathology (Carr, 2012).

For example, the slip technique characterizes a change in a purposeful, logically conditioned train of thought, in which there is a deviation from the semantic connecting line within sentences, both with a change in the topic of the utterance and without a change in the topic of the utterance. The slip in the speech of the «digital generation» is due to the redundancy of the presence of hyperlinks in the text space. The so-called jumps of thoughts, the discontinuity of the message and the incompleteness of the utterance are also associated with this phenomenon.
Modern scientists pay attention to the growth of changes in the linguocognitive communicative matrix of the youth of the digital world, drawing parallels with pathopsycholinguistic processes (Sultanova, Ivanova, 2017) and the transformative nature of clip thinking of the modern young generation for human civilization (Karr, 2012; Barkhatova et al., 2021). We believe that it is more correct to talk about multitasking and switchability in connection with entropic processes in human civilization in terms of the priority of the digital data flow. Under the linguocognitive communicative matrix, we understand a set of verbal and paraverbal stable signs used in communication.

The modern «digital generation» clearly regulates the priority principles of selecting information for use in communication, shortening words, phrases, sentences, etc., since the thinking of students of the «digital generation» is strikingly different from the thinking of teachers, experts who were formed in the pre-

Table 1. Changes in the speech-thinking behavior of students of the digital era (compiled by us based on the responses of respondents-I. K.)

\begin{tabular}{|c|l|c|c|c|c|}
\hline \multirow{2}{*}{ № } & \multirow{2}{*}{ The ratio of signs and values } & \multicolumn{3}{|c|}{ Respondents' responses by country (\%) } \\
\cline { 3 - 5 } & & Greece & Australia & Russia & Kazakhstan \\
\hline 1 & Narrowing the lexical meaning & $25 \%$ & $37 \%$ & $20 \%$ & $18 \%$ \\
\hline 2 & Excessive detail & $28 \%$ & $32 \%$ & $31 \%$ & $29 \%$ \\
\hline 3 & excessive abstraction and generalization & $27,95 \%$ & $27,38 \%$ & $16,86 \%$ & $27,81 \%$ \\
\hline 4 & Priority of abstract vocabulary & $30,24 \%$ & $31,18 \%$ & $30,71 \%$ & $30,71 \%$ \\
\hline 5 & Neologisms and new meanings & $37,7 \%$ & $28,23 \%$ & $23,54 \%$ & $33,42 \%$ \\
\hline 6 & $\begin{array}{l}\text { Superstructure of signs over oth- } \\
\text { er signs, the use of graphemes }\end{array}$ & $42 \%$ & $50,9 \%$ & $49,4 \%$ & $44 \%$ \\
\hline 7 & Combining different characters & $16,7 \%$ & $17,2 \%$ & $5,1 \%$ & $3,8 \%$ \\
\hline 8 & Excessive concretization of judgments & $29,3 \%$ & $31,5 \%$ & $14,8 \%$ & $43,19 \%$ \\
\hline 9 & Pretentiousness of judgments & $31,3 \%$ & $34,8 \%$ & $26,7 \%$ & $29,9 \%$ \\
\hline 10 & Paradoxical & $41,1 \%$ & $43,4 \%$ & $34,7 \%$ & $36,8 \%$ \\
\hline 11 & Slipping off & $27,3 \%$ & $46,23 \%$ & $33,12 \%$ & $32,18 \%$ \\
\hline 12 & Alogisms & $14,3 \%$ & $13,32 \%$ & $12,78 \%$ & $11,91 \%$ \\
\hline 13 & Formalisms & $9,87 \%$ & $13,89 \%$ & $23,41 \%$ & $7,89 \%$ \\
\hline 14 & Superinclusions & $7,35 \%$ & $11,81 \%$ & $12,58 \%$ & $22,71 \%$ \\
\hline 15 & Updating hidden values & $14,51 \%$ & $17,33 \%$ & $21,22 \%$ & $21,38 \%$ \\
\hline 16 & Inadequacy & $27,81 \%$ & $39,22 \%$ & $24,55 \%$ & $24,38 \%$ \\
\hline 17 & Reasonableness & $29,31 \%$ & $35,3 \%$ & $28,26 \%$ & $21,34 \%$ \\
\hline 18 & Expressive syntax & $31,81 \%$ & $49,6 \%$ & $37,35 \%$ & $29,82 \%$ \\
\hline
\end{tabular}


digital era and perceive such a model as flawed, pathological, and non-normative (Carr, 2012). As a result, we are dealing with the pseudopathology of speech-thinking processes in the «digital generation» (Grekova, 2019).

At the same time, we observe a rather frivolous attitude to language rules and standards, spelling, orthoepy, grammar, since one of the most important dominants in the behavioral matrix of the "digital generation» is the attitude to time.

As we can see, speed and the desire to succeed become the leading motivators in the linguocognitive communicative matrix of «digital students», which inevitably entails a «train» of various mistakes. Thus, lexical, and grammatical errors occur in $83 \%$ of cases when studying Russian in a Greek audience in an online educational discourse. Russian «digital students» studying the Kazakh language in Kazakhstan make $54 \%$ of such mistakes when using online educational discourse. Students who have arrived in Australia to study English make fewer mistakes (34\%), which is due to the preliminary in-depth study of the English language and the selection of potential students by passing international-level English language proficiency exams. Russian language learners, a control group of educational migrants in Russia, also show a high percentage of such errors, which is associated with the complexity of the initial study of the Russian language outside the language environment.

At the same time, a group of Russianspeaking students of Russia and Kazakhstan, specializing in English, shows $49 \%$ of errors of this kind. At the same time, the conditions of the pandemic have made the training format more stereotypical and schematic, without the possibility of full immersion in the language environment of the studied country, which also exacerbates the difference in the perception and analysis of information from the point of view of «digital» and «predigital» generations.

In addition, the digital generation is characterized by an increased level of intactness in real communication with a predominance of involvement in communication in digital reality, and therefore written speech, rather than oral speech, becomes the leading method of communication. At the same time, written speech increasingly acquires the features of oral speech among representatives of the «digital generation» (the so-called «expressive syntax»-I. K.). Does this mean that the student's communicative competencies are not formed? Or are we dealing with the evolution of the communicative competence of the digital generation of students?

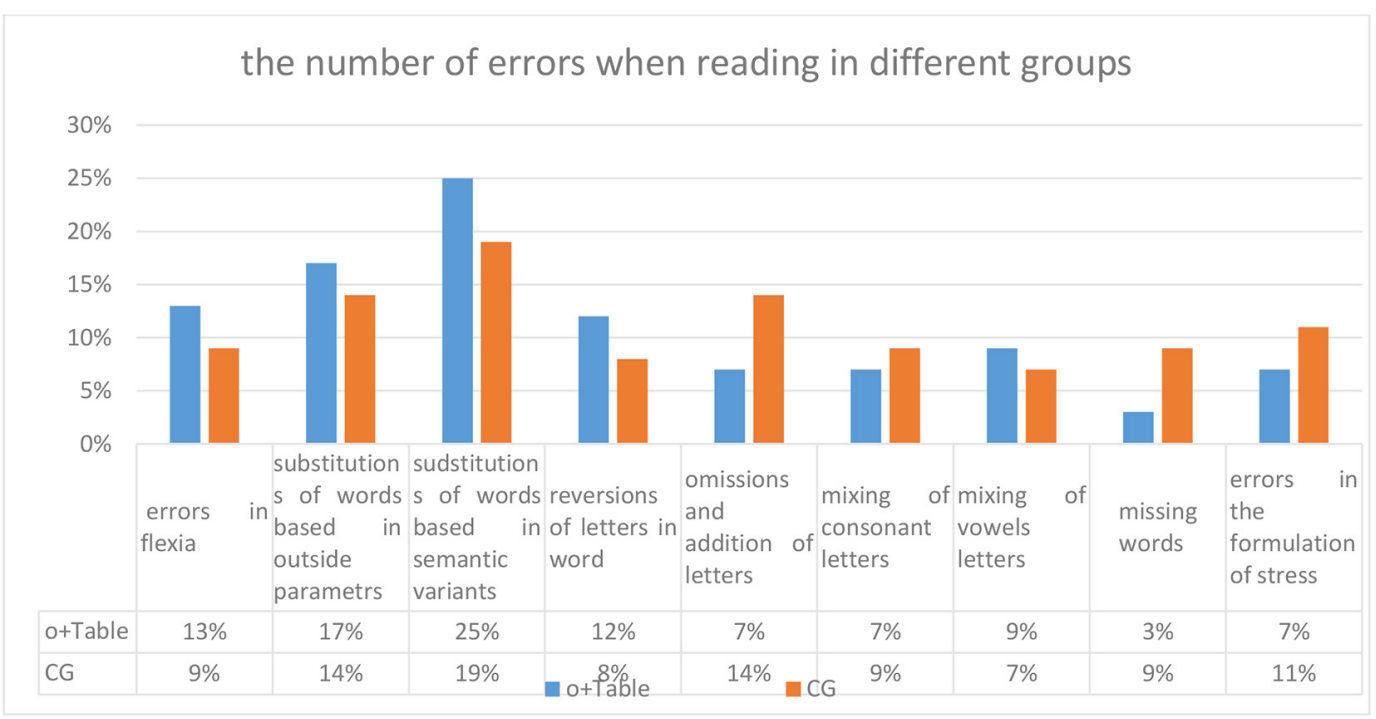

Fig. 2. The number of errors when reading the experimental and control groups (CG -control group) 
The situation of the behavioral matrix of modern students is illustrated in Figure 3. Types of communication: The percentage ratio of the level of formation of the development of communicative competence by types of communication among the digital generation of students.

Students of the «digital generation» demonstrate the priority of the organization of thinking in the aspect of visualizing its form, which makes it possible to correlate the organization of thinking with the Network rather than with a linear hierarchy, reflecting the processes of «merging» natural speech-thinking activity with the artificial environment of the Internet.

The involvement of students of the «digital generation» in communication gives an understanding of the effectiveness of the main five types of communicative situations (Table 2).

At the same time, the speed of information processing in the «digital generation» increas- es significantly. Although $80 \%$ of students in the online educational discourse are intact, but $60 \%$ of them demonstrate a high level of formation of communicative competence, $30 \%$ have an average level and $10 \%$ have a low level. In addition, we believe that it is necessary to pay close attention to the following types of situations 2 and 3, and not to lose sight of types 4 and 5.

We consider the increase in the number of changes in the linguocognitive and behavioralcommunicative matrix of the «digital generation» as an illustration of the invariant of the norm of speech-thinking processes.

The new type of thinking is characterized by plasticity, versatility, volume, polyvaritiveness. At the same time, the boundary between the sign and the meaning along the line «abstractness-concreteness» is very ambiguous and mobile, since the «digital generation» of native speakers perceives signs as

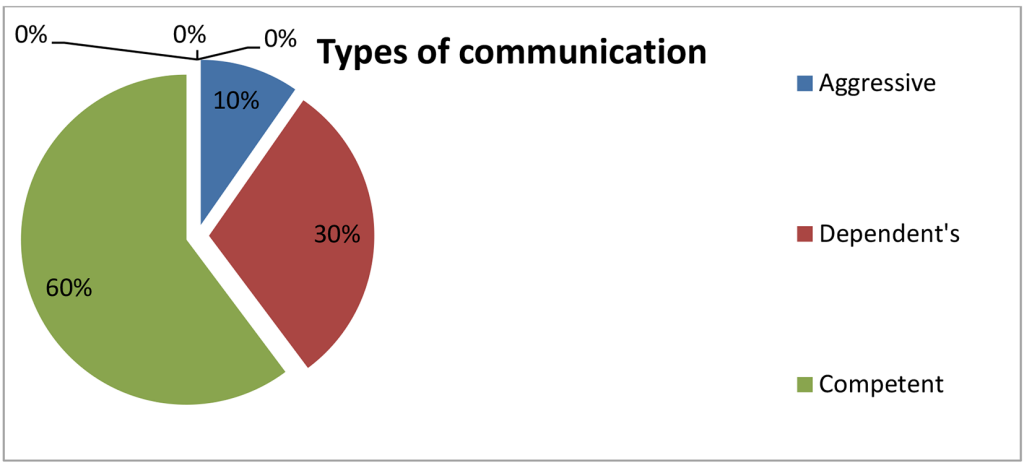

Fig. 3. Types of communication: The percentage ratio of the level of formation of the development of communicative competence by types of communication among the digital generation of students

Table 2. The level of formation of communicative competence in communicative situations in universities that participated in the experiment (number of students)

\begin{tabular}{|c|l|c|c|c|}
\hline № & \multicolumn{1}{|c|}{ Situation's } & Competent & Dependent's & Aggressive \\
\hline 1 & $\begin{array}{l}\text { - situations in which a reaction to the partner's positive } \\
\text { statements is required }\end{array}$ & 32 & 16 & 10 \\
\hline 2 & $\begin{array}{l}\text { - situations in which there should be reactions to nega- } \\
\text { tive statements }\end{array}$ & 46 & 21 & 26 \\
\hline 3 & - situations in which a request is made & 52 & 27 & 14 \\
\hline 4 & - conversation situations & 52 & 37 & 6 \\
\hline 5 & - situations in which empathy is required & 32 & 9 \\
\hline
\end{tabular}


the designation of a hyperlink, therefore, the architecture of the speech-thinking space itself is a hypertextual reality, where new signs are built on top of previous signs, but at the same time they (these new signs) string meanings on themselves.

At the same time, there is a need to distinguish with real pathopsycholinguistic phenomena, which were presented in sufficient detail in the fundamental work of the German researcher T. Spoerri (1964), which has not yet lost its theoretical and practical significance in the aspect of understanding speech features in various psychopathological and borderline states with them. For example, he points out that epileptics have a slow, unclear, «viscous» speech, in which perseverations (repetitions), stereotypical construction of constructions, macaronisms, priority use of words in a diminutive form are widely represented. At the same time, schizophrenia is characterized by reasonableness and thoroughness of speech. At the same time, the speech of a schizophrenic is distinguished by semantic discontinuity while preserving the grammatical integrity of the sentence, an abundance of complex syntactic constructions, substitutions of concrete words with abstract and vice versa, author's neologisms (Spoerri,1964). If we compare these pathopsychological characteristics of the speech of people of the pre-digital era with the features of the speech of the youth of the «digital generation» (see Table 1), we will clearly see some parallels.

In this regard, the online educational discourse is forced to reflect a new logic of thinking, therefore it has a different structural composition, and selects the content of the educational material and information content differently. For example, the training material is maximally compressed and visual, but at the same time it is built as a hyperspace with the possibility of including an extended version, in which the role of hyperlinks is performed by various detailed text explanations, as well as additional various multimedia subspaces (audio, video comments, screencasts, additional graphic and photo illustrations, short training videos created by the type of «viral» Tick-Tok clips).
The construction of an online educational discourse corresponds to the expressive syntax that is common in speech manipulation (Kopnina, 2012). As a rule, the syntactic strategies of online educational discourse are inversive: they go from the answer to a specific question, reaching up to general theories in an ascending line. The specifics of the thinking of the «digital generation» determines the strategy of emphasized visibility in the online educational discourse, which actualizes:

a) the preference of tasks for problematization; b) the use of specific examples; c) the priority of exercises- «challenges» that demonstrate to students the need to acquire skills, skills, and experience to solve problems.

Thus, the online educational discourse not only reflects the peculiarities of speech and thinking of students of the «digital generation», but also seeks to include in the linguocognitive metaparadigma of modern communicativeoriented linguodidactics a new emerging balance between language and man as an evolving social object of «digital reality», acting as an interactive linguistic, speech-thinking, and behavioral picture of the world.

\section{Discussion}

Modern linguodidactics is faced with the need to search for new scientific and methodological approaches to the development of online educational discourse under restrictions due to the COVID-19 pandemic (Agranovich et al., 2020; Hurley, 2020; Fedunova, 2021; Gallè et al., 2021) and the crisis of the educational system due to the breaking of the worldview paradigms of the pre-digital and digital society (Ebzeeva et al., 2018; Brodovskaya, 2019; Barkhatova et al., 2021; Milošević, Maksimovich, 2020), which affected the functioning of the speech-thinking mechanism of perception itself (Alefirenko et al., 2021; Arsaliev, Andrienko, 2021; Grishina, Abakumova, 2020; Karabulatova, Polivara, 2012).

Most modern training courses in a particular language are focused on the formation of ethno-linguistic and cultural and communicative competencies among students (Arakin, 2016; Petuch, 2004; Polychronidou, 2013; Belbotayev, Bulanbayeva, 2007). The very situa- 
tion of online educational discourse requires a high level of emotional intelligence and professional competencies in the context of a pandemic (Aipova et al., 2021; Grishina, Abakumova, 2020; Lugovsky et al., 2018; Nijiati et al., 2020; Fedunova, 2021; Tleuzhanova et al., 2021).

However, the analysis of the proposed ethnopedagogical models of the formation of communicative competence (Krotik, Morhun, 2021; Martazanov et al., 2021) does not include, paradoxically, a linguistic component, implying that the language is included in the default structure. However, such an omission of the linguistic component in the structure of the educational language discourse devalues the language component itself in the linguodidactic process, sending the formation of the understanding of language as a system to the periphery.

At the same time, the model itself usually includes historical and regional components, cultural components (Krotik, Morkhun; 2021; Martazanov et al., 2021), etc. In this regard, we believe that such an implementation of educational discourse, especially online educational discourse, leads to the inevitable destruction of ethnopsycholinguistic norms (Karabulatova, Polivara, 2012), which are the foundation for the formation of all forms of human identity, starting from gender and ending with civil identity. I.S. Karabulatova, Z. V. Polivara introduced the term «ethnopsycholinguistic norm» as an indicator of the conformity of knowledge, understanding and application of the norms of language, culture, psychology, and history of the native and/or foreign language in the speaker's own speech (Karabulatova, Polivara, 2012).

However, the modern accelerated rhythm of human life «smears» the details of being, including in its verbal representation, focusing only on distinguishing the parameters «important/ unimportant», without observing the norms and rules of language. As a result, the polyphony of the online educational discourse is formed, which reflects the structural shifts in human consciousness under the influence of digital reality (Grishina, Abakumova, 2020; Zvezdina, 2015). We agree with the opinion of researchers that virtual reality triggers the hypertextuality of modern human thinking (Zvezdina, 2015; Grekova, 2019). At the same time, such a complex organization inevitably affects the nature of speechthinking processes among representatives of the "digital generation», becoming an occasion for scientific discussions about language, thinking and speech, about the possibilities of modern human evolution, about the prognostics of human civilization (Karasik, 2016; Kholodnaya, 2002; Karr, 2012).

In some cases, researchers write about apocalyptic signs of human civilization, which is moving towards dehumanization and death in an entropic dance of agony, fixing its every step in this direction in a communicative virtual space (Kolin, 2011; Vorontsova, 2016).

Modern scientists conclude that the speech of representatives of the «digital generation» reveals quite a lot of parallels with the pathopsychological characteristics of speech in people of the «pre-digital generation» (Alyokhin, Grekova, 2018; Grekova, 2019; Zaretskaya, 2017), which reflects the restructuring of the work of speech-thinking processes in the aspect of hypertextuality and associativity (Katrechko, 2004; Luchinkina, 2016).

Apparently, all this reflects the fact that the pace of modern life has surpassed the rate of generational change, and the pace of progress has surpassed the speed of evolution of the human brain, transforming the human worldview (Kurzweil, 2005; Emelianenko, 2017; Korotaev et al., 2010). A modern person of digital time operates in his consciousness not with concepts, not logos, but with eidos, emotions, pictures-images (Lysak, Belov, 2013), which allows him to perceive and evaluate information faster, but with a loss of the quality of evaluation.

In other words, we can say that the biological singularity has already occurred, because of which we observe the transition of the thinking algorithm from a linear type to a nonlinear type. The very essence of the singularity of Big History has been discussed by scientists very actively recently in the interpretation of the characteristics and signs of canonical milestones (Kurzweil, 2005; Korotaev, 2018, Naza- 
retyan, 2013; Huebner, 2005), causing an ambiguous reaction in society.

At the same time, researchers point to the growth of autism spectrum disorders in the «digital era» (Khaustov, Shumsky, 2021), demonstrating that the main, dominant disorder leading to the appearance of other speech disorders is the lack of adequate feedback to the internal program from later stages of speech generation. This leads to the disintegration of the program itself, «hanging in the air», to the «blurring» of meanings that are not controlled by the context, the situation, objective, social meanings, which in turn leads to the disintegration of the laws of word choice, etc. (Leontiev et al., 1973; Golenkov, 2008).

This organization of speech-thinking activity increases the gap between the sign and the meaning, which characterizes the modern process of transition to a higher level of abstraction of signs as an illustrative component of the ongoing evolution of human civilization in terms of culture and thinking (Solomonik, 2012).

The effect of online educational discourse is correlated with the polycode impact of modern mass communication (Shehi et al., 2020), which manifests itself «in the totality of the consequences of influence: cognitive (attitudes, ideas, value orientations, «agenda»); affective (feelings of concern and fear, morale, social alienation); behavioral (activation of activity; direction of action)» (Brodovskaya et al., 2019: 233).

The clipping or fragmented thinking of modern youth is positioned in the scientific literature from the point of view of the generation of researchers of the pre-digital era, which is not quite correct (Carr, 2012; Mityagina, Dolgopolova, 2009; Popov, 2016). Apparently, we are dealing with an evolutionary step in the development of human neuropsycholinguistic abilities, which indicates the continued development of humans as a species (Ioileva, 2014; Zagidullina, 2012).

The linguocognitive conflict in the online educational discourse occurs due to the collision of basic concepts in the world pictures of the «pre-digital» and «digital» generations. At the same time, the conflict itself is aggravated due to multiculturalist tendencies that seek to create a unified transnational identity, which is a provocative moment in the context of the crisis of local ethno-cultural and national identities, manifested in long-term interethnic conflicts not only on the world periphery, but also in highly developed countries (Mkrtumova et al., 2016).

An analytical approach to the comparison of extralinguistic and intralinguistic factors requires a special approach in the educational discourse in the era of social changes to form a value picture of the world for the younger generation (Kattsina, Karabulatova, 2020). At the same time, ignoring or suppressing these problems increases the degree of «social schizophrenia» in society, stigmatizing them in the public consciousness (Pashkovsky, 2017).

Unfortunately, most teachers of philology rely on the worldview paradigm of the «predigital generation», promoting the principles of ethnooriented teaching, which historically developed in the era of Tsarist Russia and was actively used on the outskirts of the Russian Empire (Degtyarev et al., 2021). However, the lack of ethno-pedagogical communicative competence and the transfer of the template to modern realities among students often play a «cruel joke» with teachers working with foreign students. For example, students who speak Arabic may belong to different peoples and even to different religions (Al-Nofaye, 2020; Dubinina, Kovyrshina, 2008). Chinese students may also belong to different peoples of China with different cultures. Students from Russia may ethnically belong to other ethnic groups, religions and cultures that are strikingly different from Russian culture. As a result, the teacher may get into a situation of «methodological confusion». All this only emphasizes the importance of considering the chronotope in the research of the linguistic cycle, which makes it possible to calculate the probability of transformation of language tiers and language consciousness during periods of tension.

At the same time, the restructuring of thinking in connection with the strengthening of digitalization processes has also exacerbated 
the problem of socialization of students in the online educational discourse of the pandemic period (Ukrainian, 2020; Stoiljković, 2020). The researchers emphasize the cyclical nature of the occurrence of such situations and their coincidence in the chronotope with periods of social crisis (Kurzweil, 2005; Marinenko et al., 2019; Avdee, 2021; Korotaev et al., 2010), demonstrating the breakdown of the previous value worldview paradigm.

\section{Conclusion}

The linguistic and communicative register of online educational discourse acts as a model of speech educational activity, in which the trinity of «student-teacher-Internet space» interacts with their communicative intentions, a certain repertoire of ethno-cultural, linguisticpedagogical, and pragmatic-communicative markers in combination with other verbal and non-verbal means.

Considering the communicative aspect of the analysis of the online educational discourse of the speech behavior of representatives of the «digital generation», it is necessary to consider the register to which the verbal marker or its accompanying word belongs, in order to distinguish it from psychopathological states and pseudopathopsycholinguistic phenomena of the speech of the «digital generation» (Grekova, 2019). Ignoring this important aspect of the transformation of the language organization of the «digital generation» entails a generational conflict and aggression towards each other, which is much more difficult to correct.

Online-educational discourse forms subspaces of:

A) differential units (discourses that are characterized by a direct and intentional collision of the subjects' communicative goals);

B) potential units (discourses that are characterized by an indirect and unintentional collision of the subjects' communicative goals).
The process of preparing an online educational discourse is based on the skills and abilities of working with information technologies (Fedunova, 2021), taking into account the specifics of the thinking of the generation of the «digital era», which allows updating existing knowledge, activating human research activities.

It is obvious that we are in the process of transforming the traditional social model of learning due to the COVID-19 pandemic, the dominant information and communication technologies due to the technological leap that caused global changes in the thinking model itself, bringing the evaluation model of natural language closer to the created artificial models of neural networks. This process of interaction is vividly illustrated by observations of the transformation of the speech-thinking skills of the «digital generation» when mastering a language (native / non-native), which tends to keep up with technological processes in speed, while losing the qualitative assessment and decoding of information. This is one of the evolutionary steps of human speech-thinking activity, so experts are extremely cautious about categorical assessments, suggesting that these phenomena of language reduction be designated as pseudopsychopathological phenomena.

We assume that the next step will be associated not just with increasing the speed of assimilation and transmission of information but will be aimed at a qualitative selection of verbal and non-verbal means of communication that can convey a thought as accurately as possible. In the future, a clearly formulated algorithm of a particular case can help to identify hidden deviations, potential social dangers, preventing various kinds of provocations of ethnic and socio-cultural conflicts, contributing to the formation of multi-aspect communicative competence using machine learning technologies.

\section{References}

Agapova, I. V., Gorbunova, V. S (2014). Osobennosti avstraliyskogo varianta angliyskogo yazyka [Features of Australian English] in Perspektivy nauki i obrazovaniya [Science and Education Perspectives], 3, 9: 142-146. URL: https://cyberleninka.ru/article/n/osobennosti-avstraliyskogo-varianta-angliyskogo-yazyka [in Russian] 
Agranovich, M. L., Ermachkova, Yu.V., Livanets, M. A. (2020). Onlayn-obucheniye v period pandemii COVID-19 i neravenstvo dostupa k obrazovaniyu [Online learning during the COVID-19 pandemic and inequality in access to education] in Federalism, 3: 188-206 https://doi.org/10.21686/2073-1051-2020-3188-206_[in Russian]

Aipova A., Apaeva A., Temirgalinova A., Shabambaeva A., Karabulatova I. (2021). The features of the formation of ethno-value consciousness in the modern Kazakh Pedagogical University in EduWEB. Revista de Tecnología de Información y Comunicación en Educación, 15, 2: 229-244, DOI: https://doi. org/10.46502/issn.1856-7576/2021.15.02.18

Alefirenko, N. F., Nurtazina, M. B., Stebunova, K. K. (2021). V poiskakh kognitivno-lingvisticheskoy metodologii ucheniya o diskurse [In search of a cognitive-linguistic methodology for teaching about discourse] in Bulletin of St. Petersburg State University. Language and Literature, 18, 2: 313-338. DOI: 10.21638/spbu09.2021.205 [in Russian]

Alyokhin, A. N., Grekova, A. A. (2018). «Psevdopsikhopatologicheskiye» formy myshleniya v sovremennykh usloviyakh [«Pseudopsychopathological» forms of thinking in modern conditions] in Bulletin of Psychotherapy, 66, 71: 137-151[in Russian]

Amiridou, S. (2017). To be or not to be? Russian language in Greece 30 years later in CCS\&ES, 3: $14-22$.

Arakin, V. D. (2016). Prakticheskii kurs anglijskogo yazyka. 5 kurs [Practical English course for 5th year students]. M., 229 p. https://ru.pdfdrive.com/Практический-курс-английского-языка-5-курсУчебник-е186895584.html [in Russian]

Arsaliev Sh. M. - Kh., Andrienko A. S. (2021). The Development of Ethnocultural Competence of University Students During COVID-19 Pandemic in Russia. Proceedings of the 2020 3rd International Seminar on Education Research and Social Science (ISERSS2020). Advances in Social Science, Education and Humanities Research: 46-50. https://doi.org/10.2991/assehr.k.210120.010

Baker Sidney J. (1945). The Australian Language, London-Sidney: Angus \& Robertson, 415 p. https:// archive.org/details/in.ernet.dli.2015.58344

Barkhatova D. A., Simonova A. L., Lomasko P. S., Khegay L. B. (2021). Features of «Inverted» Educational Resources for Distance Learning of Pupils. Open Education, 25, 4: 4-12. https://doi.org/10.21686/1818 4243-2021-4-4-12 [In Russian]

Belbotayev, A., Bulanbayeva, Zh. (2007). Rukovodstvo po izucheniyu gosudarstvennogo yazyka [Guide for the study of the state language]. Almaty: Globus, 2007, 216 p. [In Russian]

Beregovaya, N. Yu., Karlova, O.A. (2020). Ideological Phantoms of Civilisation and Culture: Identity and Tolerance, Journal of Siberian Federal University. Humanities \& Social Sciences. 13 (7): 1090-1098, DOI: 10.17516/1997-1370-0413

Brodovskaya, E. V., Dombrovskaya, A. Yu., Pyrma, R.V., Sinyakov, A.V., Azarov, A.A. (2019) The impact of digital communication on Russian youth professional culture: results of a comprehensive applied study. Monitoring of Public Opinion: Economic and Social Changes, 1: 228-251. https://doi.org/10.14515/ monitoring.2019.1.11.

Carr, N. (2012). Pustyshka. Chto internet delayet s nashimi mozgami [Dummy. What the internet is doing to our brains] Transl. P. Mironov. SPb.: Best Biznes Buks,356 p. [in Russian]

Davtyan-Iokamidi, I. (2015). Osobennosti prepodavaniya russkogo yazyka v grekoyazychnoy auditorii [Features of teaching the Russian language in the Greek-speaking audience] in Elektronnoye nauchnoye izdaniye Al'manakh Prostranstvo $i$ Vremya [Electronic scientific publication Almanac Space and Time], 8, 1, https://cyberleninka.ru/article/n/osobennosti-prepodavaniya-russkogo-yazykagrekoyazychnoy-auditorii

Druzhinin, P. V., Molchanova, E. V. (2021). The First and Second Waves of the COVID19 Pandemic in the Russian Regions: Comparison of the Change in the Mortality Rate. Journal of Siberian Federal University. Humanities \& Social Sciences. 14(7): 1028-1038, DOI: 10.17516/1997-1370-0782

Dubinina, N. V., Kovyrshyna, N. B. (2008). K voprosu o formirovanii I razvitii obrazovatel'nogo prostranstva v stranakh Blizhnego Vostoka 9na primere Izrailya) [On the formation and development of ed- 
ucational space in the Middle East (on the example of Israel)] in Bulletin of Peoples' Friendship University of Russia: Series: Educational issues: Languages and specialties, 3: 133-137. [in Russian]

Ebzeeva, Yu. N., Karabulatova, I. S., Nakisbaev D. A. (2018). The Problems of Transformation of the Personal Identity in a Modern Migrant in Astra Salvensis, 11 (1): 729-738.

Emelyanenko, V. D. (2017). Internet i dukhovnyy mir cheloveka: tsennostno-mirovozzrencheskiy podkhod [The Internet and the Human Spiritual World: Value and Worldview Approach] in Minin University Bulletin, 4 (21), 12 p., DOI: 10.26795/2307-1281-2017-4-12 [in Russian]

Galskova, N. D., Gez, N. I. (2009). Teoriya obucheniya inostrannym yazykam. Linvodidaktika I metodika [Theory of teaching foreign languages. Linguodidactics and methodology]. M.: Akademiya, 458 p.

Gallè F, Veshi A, Sabella EA, Çitozi M, Da Molin G, Ferracuti S, Liguori G, Orsi GB, Napoli C, Napoli C. (2021). Awareness and Behaviors Regarding COVID-19 among Albanian Undergraduates. Behav Sci (Basel), 11. 4: 45. doi: 10.3390/bs11040045. PMID: 33807250; PMCID: PMC8067270.

Gervilla, E. F. Q., García, I. S. (2020). Communicative and Textual Competence as a Formative Element in the Subject of Translation in Science and Technology (Russian - Spanish). Journal of Siberian Federal University. Humanities \& Social Sciences 3(3): 352-362, DOI: 10.17516/1997-1370-0352

Golenkov, A. V. (2008) Narusheniya myshleniya i rechi u bol'nykh shizofreniyey s defitsitarnymi proyavleniyami [Thought and speech disorders in schizophrenic patients with deficits] in Bulletin of psychiatry and psychology of Chuvashia, 4: 8-17. [in Russian]

Govor, E. A. (2018). V poiskakh ranney russkoy diaspory v Avstralii[In Search of the Early Russian Diaspora in Australia] in Traditsionnaya kul'tura [Traditional Culture], 19 (4), 44-56. [in Russian]

Grekova, A. A. (2019). Osobennosti myshleniya predstaviteley «tsifrovogo pokoleniya» [Features of thinking of representatives of the «digital generation»] in Psychology. Psychophysiology, 1: 28-38. DOI: 10.14529/psy190103

Grishina, A.V., Abakumova, I. V. (2020). Informational behavior in the COVID-19 pandemic: psychological predictors, International Journal of Cognitive Research in Science, Engineering and Education (IJCRSEE), (8), Special issue of Current Research and Trends in Cognitive Sciences 2020, 59-67. https://doi. org/10.23947/2334-8496-2020-8-SI-59-67

Edwards, E. (2018). Embracing action research: Current tensions and possible directions, English Australia Journal: The Australian journal of English language teaching, 34, 1, 3-21.

Huebner, J. (2005). A Possible Declining Trend for Worldwide Innovation. Technological Forecasting and Social Change 72(8): 980-986.

Hurley, P. (2020). Coronavirus and international students. Mitchell Institute, Victoria University. Melbourne, 30 p. https:/www.vu.edu.au/sites/default/files/international-student-update-2020-mitchellinstitute.pdf

Fedunova, M.N. (2021). Problemy distantsionnogo obucheniya inostrannym yazykam v usloviyakh pandemii [Problems of distance learning foreign languages in pandemic conditions] in Simvol nauki [Symbol of Science], 3, 119-123 [in Russian]

Informburo.kz, 5.11.2019. Uroven' vladeniya angliyskim yazykom v Kazakhstane snizhayetsya tretiy god podryad [The level of English proficiency in Kazakhstan has been declining for the third year in a row]. Electronic resource: https://informburo.kz/novosti/uroven-vladeniya-angliyskim-yazykom-v-kazahstanesnizhaetsya-tretiy-god-podryad.html [in Russian]

Ioyleva G. V. (2014). Soznaniye v sfere informatizatsii obshchestva [Consciousness in the field of informatization of society] in Bulletin of the Northern (Arctic) Federal University. Series: Humanities and Social Sciences, 4: 36-41. [in Russian]

Kanevskaya G. I. (2007). Russkaya immigratsiya I rossiysko-avstraliyskiye otnosheniya (k 200-letiyu ustanovleniya kontaktov mezhdu Rossiey I Avstraliey [Russian immigration and Russian-Australian relations (to the 200th anniversary of the establishment of contacts between Russia and Australia)] in Vestnik DVO RAN [Bulletin of the Far Eastern Branch of the Russian Academy of Sciences], 5: 65-74 [in Russian]

Karabulatova, I.S. (2020). Possibilities of artificial intelligence in assessing the impact of potentially dangerous texts in modern news discourse: problem of statement Published online: 24 December 2020. In- 
ternational Scientific Forum «Issues of Modern Linguistics and the Study of Foreign Languages in the Era of Artificial Intelligence (dedicated to World Science Day for Peace and Development)》 (LLT Forum 2020) Volume 88, 2020, p. 1-12. DOIhttps://doi.org/10.1051/shsconf/20208801001

Karabulatova, I.S., Polivara, Z.V. (2012). K ponyatiyu etnopsikholingvisticheskoy normy u deteybilingvov [On the concept of ethnopsycholinguistic norms in bilingual children] in Spetsial'noye obrazovaniye [Special Education], 1: 22-29

Karabulatova I. S., Lagutkina M.D., Amiridou, S. (2021). The Mythologeme «Coronavirus» in the Modern Mass Media News in Europe and Asia. Journal of Siberian Federal University. Humanities \& Social Sciences. 14(4): 558-567, doi: 10.17516/1997-1370-0742

Karabulatova, I., Ldokova, G., Bankozhitenko, E., Lazareva, Yu. (2021). The role of creative musical activity in learning foreign languages, Thinking Skills and Creativity, 41: 100917, https://doi.org/10.1016/j. tsc.2021.100917.

Karabulatova, I.S., Lagutkina, M.D., Borodina, N.V., Streltsova, M.A., \& Bakhus, A.O. (2021). Formation of ethnosocial identity in the matrix of media discourse in Amazonia Investiga, 10(43): 234-247. https://doi.org/10.34069/AI/2021.43.07.23

Karasik, V. I. (2016). Diskursivnoye proyavleniye lichnosti [Discursive manifestation of personality] in Bulletin of RUDN. Series: Linguistics, 4: 56-77. [in Russian]

Katrechko, S. L. (2004). Internet i soznaniye: k kontseptsii virtual'nogo cheloveka [Internet and Consciousness: Towards the Concept of a Virtual Human] in Vliyaniye interneta na soznaniye i strukturu znaniya [Influence of the Internet on Consciousness and the Structure of Knowledge]. M.: 57-73. [in Russian]

Katssina T., Karabulatova I. (2020). Social control of offenses minors: perception and interpretation in Soviet Russia at an early stage (1917-1921), Terra Sebus, 12: 243-262

Khaustov, A. V., Shumskikh, М. А. (2021). Хаустов А. В., Шумских М. А. Dinamika v razvitii sistemy obrazovaniya detey s rasstroystvami autisticheskogo spektra v Rossii: rezul'taty Vserossiyskogo monitoringa 2020 goda [Dynamics in the development of the education system of children with autism spectrum disorders in Russia: the results of the All-Russian monitoring 2020] in Autism and developmental disabilities, 19, 1, 70: 4-11. DOI: https://doi.org/10.17759/autdd.2021190101 [in Russian]

Kholodnaya, M. A. (2002). Psikhologiya intellekta: Paradoksy issledovaniya [The Psychology of Intelligence: The Paradoxes of Research], Ed.2, SPb: Piter, 119-127 [in Russian]

Kolin, K. K. (2011). Informatsionnaya antropologiya: pokoleniye Next i novaya ugroza psikhologicheskogo rassloyeniya chelovechestva $\mathrm{v}$ informatsionnom obshchestve [Information anthropology: the Next generation and the new threat of psychological stratification of humanity in the information society] in Bulletin of the Chelyabinsk State Academy of Culture and Arts, 4: 32-36. [in Russian]

Korotaev, A. V. (2018). Gorizonty XXI veka: matematicheskiy analiz gipotezy singulyarnosti [Horizons of the XXI century: a mathematical analysis of the singularity hypothesis] in Historical psychology and sociology of history, 2: 5-60, DOI: 10.30884/ipsi/2018.02.01 [in Russian]

Korotaev, A. V., Khalturina, D. A., Malkov, A. S., Bozhevolnov, Yu. V., Kobzeva, S. V., Zinkina, Yu. V. (2010). Zakony istorii: Matematicheskoye modelirovaniye i prognozirovaniye mirovogo i regional'nogo razvitiya [The laws of history: Mathematical modeling and forecasting of world and regional development]. Ed. A. V. Korotaev, Yu. V. Zinkina. Ed. 3rd, noun revised and add., M.: Publishing house LCI, 344p. [in Russian]

Kopnina, G. A. (2012). Rechevoye manipulirovaniye: uchebnoye posobiye [Speech manipulation: a tutorial]. Moscow: Flinta, 4th ed., 170, p.; ISBN978-5-9765-0060-0 [in Russian]

Khudorenko, E. A. (2020). YAzykovaya politika Rossii v kontekste yevraziyskoy integratsii [Language policy of Russia in the context of Eurasian integration] in Political Science, 2: 163-182. - DOI: http://www.doi.org/10.31249/poln/2020.02.08 [in Russian]

Krotik, K.V., \& Morhun, O.O. (2021). The Development of Intercultural Competence of Secondary School Pupils and University Students, Arab World English Journal (AWEJ) Special Issue on Covid 19. Challenges, 1: 244-263. DOI: https://dx.doi.org/10.24093/awej/covid.19 
Kurzweil, R. (2005). The Singularity is Near: When Humans Transcend Biology. New York: Viking Penguin, 680 p. Retrieved from: https://archive.org/details/singularityisnea00kurz

Leontyev, A. A., Rokhlin L.L., Savitskaya, A. B., Shakhnorovich, A. M. (1973). Klinikopsikholingvisticheskoye issledovaniye razorvannosti rechi u bol'nykh paranoidnoy formoy shizofrenii in Clinical and psycholinguistic study of speech disruption in patients with paranoid schizophrenia] in Journal of Neuropathology and Psychiatry named after S. S. Korsakov, 3, 12: 1858-1863 [in Russian]

Lin, Y., Karabulatova, I.S., Shirobokov, A.N., Bakhus, A.O., \& Lobanova, E.N. (2021). Cognitive distortions in the reflection of civic identity in China: on the material of Russian-language media of East and Western in Amazonia Investiga, 10(44), 115-125. https://doi.org/10.34069/AI/2021.44.08.11

Luchinkina, A. I. (2016). Spetsifika mirovozzreniya internet-pol'zovateley [The specifics of the worldview of Internet users] in Problems of modern pedagogical education, 51, 1: 311-317 [in Russian]

Lugovskiy, V.A., Surzhenko, L.V., Kokh, M.N. (2018). Psikhologicheskaya gotovnost' k professional'noy deyatel'nosti kak osnova konkurentosposobnosti vypusknikov vuza [Psychological readiness for professional activity as the basis of competitiveness of university graduates] in Vestnik Kostromskogo gosudarstvennogo universiteta. Seriya: Pedagogika. Psikhologiya. Sotsiokinetika [Bulletin of the Kostroma State University. Series: Pedagogy. Psychology. Sociokinetics]. 1:66-70. [in Russian]

Lysak, I. V., Belov, D. P. (2013). Vliyaniye informatsionno-kommunikatsionnykh tekhnologiy na osobennosti kognitivnykh protsessov [Influence of information and communication technologies on the peculiarities of cognitive processes] in Izvestia SFedU. Technical science, 5, (142), 256-264. [in Russian]

Marinenko L.E., Kattsina T. A., Karabulatova I. S., Mezit L.E. (2019). Historical experience of combating epidemics in the Yenisei province in the late XIX - early XX centuries, Bylye Gody, 54, 4, 1737 1744. DOI: $10.13187 /$ bg. 2019. 4. 1737

Martazanov A. M., Martazanova, Kh. M., Sarbasheva, A. M. (2021). Folklore and literary continuum in the North Caucasian novel of the late XX-th century in the aspect of ethnopedagogy, Revista de Tecnología de Información y Comunicación en Educación, 15, 2, 275-291, DOI: https://doi.org/10.46502/ issn.1856-7576/2021.15.02.21

Martynov D. Ye., Martynova YU. A., Valeyev R. M. (2018). Metody polevykh issledovaniy russkikh vostokovedov-etnografov vtoroy poloviny XIX v. (na primere N. Miklukho-Maklaya i N. Katanova) [Field research methods of Russian orientalists-ethnographers of the second half of the 19th century. (on the example of N. Miklukho-Maclay and N. Katanov)], Izvestiya Obshchestva arkheologii, istorii i etnografii pri Kazanskom universitete [the News of the Society of Archeology, History and Ethnography at Kazan University], 2, 105-117. [in Russian]

Mattheoudakis, M. and Alexiou, T. Early foreign language instruction in Greece: Socioeconomic factors and their effect on young learners' language development. The Age Factor and Early Language Learning, edited by Marianne Nikolov, Berlin, New York: De Gruyter Mouton, 227-252, https:/doi. org/10.1515/9783110218282.227

Milošević, D., \& Maksimović, J. (2020). Methodology of Comparative Research in Education: Role and Significance in International Journal of Cognitive Research in Science, Engineering and Education (IJCRSEE), 8(3): 155-162. doi: 10.23947/2334-8496-2020-8-3-155-162

Mityagina, E. V., Dolgopolova, N. S. (2009). «Klipovoye soznaniye» molodezhi v sovremennom informatsionnom obshchestve [«Clip Consciousness» of Youth in the Modern Information Society] in Bulletin of the Nizhny Novgorod University. N.I. Lobachevsky. Series: Social Sciences, 3, 15: 53-59. [in Russian]

Mkrtumova, I., Dosanova, A., Karabulatova, I., Nifontov, V. (2016). The use of communication technologies of oppose political-religious terrorism as an ethnosocial deviation in the contemporary informationdigital society, Central Asia and the Caucasus, 17, 2: 54-61. http://www.ca-c.org/journal/2016/journal_eng/ cac-02/06.shtml

Nazaretyan, A. P. (2013). Seredina XXI veka: zagadka singulyarnosti [Mid-XXI century: the mystery of the singularity] in Philosophical Sciences, 9: 15-24 [in Russian]

Nijiati, A., Karabulatova, I.S., Lin,' Yu., Sautiyeva, F. B. (2020). Problems of cognitive distortions in cross-cultural communication when using automatic translation in the Russian Chinese dialogue// Pub- 
lished online: 24 December 2020. International Scientific Forum «Issues of Modern Linguistics and the Study of Foreign Languages in the Era of Artificial Intelligence (dedicated to World Science Day for Peace and Development)» (LLT Forum 2020), 88: RUDN, 311-320, DOI https://doi.org/10.1051/shsconf $/ 20208803004$

Osipov G., Karabulatova I., Shafranov-Kutsev G., Kononova L., Akhmetova B., Loskutova E., Niyazova G. (2016). Ethnic trauma and its Echo in today's mental picture of the world among the peoples of the post-soviet states: an interethnic conflicting discourse unfolding in Russian's ethnolinguistic information space in Central Asia and the Caucasus. Journal of Social and Political Studies, 17, 2: 87-94. http://www. ca-c.org/journal/2016/journal_eng/cac-02/10.shtml

Pashkovsky, E. A. (2017). Sotsial'naya stigmatizatsiya v sovremennom obrazovanii [Social stigmatization in modern education] in Discourse. 2017; (3): 111-118. https://doi.org/10.32603/2412-8562-2017-0 3-111-118. [in Russian]

Pashkovsky, V.E., Piotrovskaya, V.R., Piotrovsky, R.G. (2015). Psikhiatricheskaya lingvistika [Psychiatric linguistics]. Ed. 4th., Moscow: URSS: Lenand, sor., 157 p. [in Russian]

Peng, R.-Z. and Wu, W.-P. (2016). Measuring intercultural contact and its effects on intercultural competence: A structural equation modelling approach, International Journal of Intercultural Relations, 53, 16-27. DOI: https://doi.org/10.1016/j.ijintrel.2016.05.003.

Petukh, I. M. (2004). Uchebnik kazakhskogo dlya russkoyaznych so srednim I vyshim obrazovaniem [Textbook of the Kazakh language for Russian speakers with secondary and higher education]. Kostanay, 2004, 124 p. [in Russian]

Polikhronidu S. Russkiy yazyk v Gretsii. Istoriya, sovremennoye sostoyaniye, perspektivy [Russian language in Greece. History, current state, prospects] in Rusistika, 1: 105-109. [in Russian]

Polivara, Z.V., I. S. Karabulatova. (2019). YAzykovaya lichnost' v transformiruyushchemsya soobshchestve: etnolingvisticheskiye differentsiatsii tatar-bilingvov v inoetnichnom okruzhenii: monografiya [Linguistic personality in a transforming community: ethnolinguistic differentiations of Tatar-bilinguals in a different ethnic environment: monograph]. 3rd ed., Ster. Moscow: FLINTA, 152 p. - ISBN978-5-97651651-9 [in Russian]

Popov, A. N. (2016). Uchebnyy diskurs kak pedagogicheskiy fenomen [Educational discourse as a pedagogical phenomenon] in Bulletin of the Orenburg State Pedagogical University. Electronic scientific journal, 4 (20), 309-316. [in Russian]

Reyting stran po urovnyu vladeniya angliyskim yazykom, 2020 [Ranking of countries by level of English proficiency, 2020], Electronic resource, https://nonews.co/directory/lists/countries/englishproficiency-index[in Russian]

Ruan, Yu., Karabulatova, I.S. (2021). The Experience of the Loss of the Motherland by Representatives of Russian Emigration in the Chinese Provinces (1905-1917) in Bylye Gody, 16(3): 1501-1510. DOI: 10.13187/bg.2021.3.1501 http://ejournal52.com/journals_n/1630573364.pdf

Rutskaya, K. A., Nazarenko, E.M., Kol'k, O.A. (2021). Educative Event as Professional Skills Transfer Method: The Young Reporters' Programme at the XXIX Winter Universiade 2019, Journal of Siberian Federal University. Humanities and Social Sciences, 14(3): 375-384, DOI: 10.17516/1997-1370-0728

Ryazantsev, S.V., Karabulatova, I.S., Mashin, R.V., Pismennaya, E.E., Sivoplyasova, S. Yu. (2015). Actual problems of human trafficking in Illegal immigration in the Russian Federation in Mediterranean Journal of Social Science, 6, 3, 1: 621-626. Doi:10.5901/mjss.2015.v6n3s1p621, http://www.mcser.org/journal/index.php/mjss/article/view/6451/6185

Sagimbayev, A. V. (2017). Kolonial'naya strategiya Velikobritanii v mezhvoyennyy period: otsenki britanskoy i amerikanskoy istoriografii 1920-1930-kh gg [Colonial Strategy of Great Britain in the Interwar Period: Assessments of British and American Historiography of the 1920s-1930s] in Society: philosophy, history, culture, 12: 160-163. DOI: 10.24158 / fik.2017.12.36 [in Russian]

Semke, V. Ya., Bokhan, N. A. (2008). Transkul'turnaya addiktologiya [Transcultural addictology]. Tomsk: Russian Academy of Medical Sciences, Siberian Branch; Tomsk Scientific Center, Research Institute of Mental Health, 588 p. [in Russian] 
Shehi E., Karabulatova I. S., Niyazova G., Khuong Thi Thu Trang (2020). Polycode content of news texts about coronavirus with proper names (PN) in electronic socio-political discourse, International Scientific Forum "Issues of Modern Linguistics and the Study of Foreign Languages in the Era of Artificial Intelligence (dedicated to World Science Day for Peace and Development)》 (LLT Forum 2020) Published online: 24 December 2020, 88, https://doi.org/10.1051/shsconf/20208801028

Spoerri, Theodor. Sprachphänomene und Psychose (1964). Basel - NY, 164 p. Retrieved from: https:// archive.org/details/sprachphnomeneun00spoe

Solomonik, A. B. (2012). Ocherk obshchey semiotiki [Essay on general semiotics], M.: URSS, 189 p., ISBN978-5-382-01332-9 [in Russian]

Solontsova, 2015 - Solontsova, L.P. (2015). Sovremennaya metodika obucheniya inostrannym yazykam (obshchiye voprosy, bazovyy kurs) [Modern methods of teaching foreign languages (general questions, basic course)]. Almaty: Evero, 2015, 373 p. [in Russian]

Stoiljković, Č. (2020). The impact of the Covid-19 pandemic on the educational work of kindergarten teachers in International Journal of Cognitive Research in Science, Engineering and Education (IJCRSEE), 8(3), 123-133, doi: 10.23947/2334-8496-2020-8-3-123-133

Sultan, D. S., Sabirova, D. R. (2018). Sovremennaya yazykovaya politika v Respublike Kazakhstan [Modern language policy in the Republic of Kazakhstan] in Kazan Bulletin of Young Scientists, 5, 8: 60-63. [in Russian]

Sultanova, A. S., Ivanova, I. A. (2017). K probleme normativnykh pokazateley v patopsikhologicheskoy diagnostike [On the problem of normative indicators in pathopsychological diagnostics] in Clinical and special psychology, 6, 2: 83-96. DOI: 10.17759/cpse.2017060207 [in Russian]

Tagiltseva Yu.R. (2018). Strategii i taktiki informatsionno-psikhologicheskoy voyny v kontekste rossiysko-britanskikh otnosheniy [Strategies and tactics of information-psychological warfare in the context of Russian-British relations] in Ecology of language and communicative practice, 4: 92-104. DOI 10.17516/2311-3499-041 [in Russian]

Tleuzhanova G. K., Syrymbetova, L. S., Mekezhanova, A.B., Sarzhanova, G. B., Kulsharipova Z.K. (2021). Subject-Based Speaking as a Method for the Development of Foreign-Language Professional Competence Among Students, Journal of Siberian Federal University. Humanities and Social Sciences, 14(3), 408-425, DOI: 10.17516/1997-1370-0731

Ukrainets I. A. (2020). Problemy prepodavaniya inostrannogo yazyka v professional'noy deyatel'nosti v period pandemii [Problems of Teaching a Foreign Language in Professional Activities during the Pandemic] in Yazyk i tekst [Language and Text], 7, 4, 61-70 [In Russian].

Vassilenko A.P., Karabulatova I. S., Vasilishina E. N., Tukaeva R. A., Barabash V. V. (2018). The conceptual sphere of fiction in the Russian and English world picture in Opción, 4, 85: 825-839, ISSN10121587/ISSNe: 2477-9385

http://www.produccioncientifica.luz.edu.ve/index.php/opcion/article/view/24037

Voronov, S. A. (2017). Kompetentsiya i kompetentnost' kak kategorii deyatel'nosti: sredstva i razlichiya $\mathrm{v}$ ponimanii [Competence and competence as categories of activity: similarities and differences in understanding] in Istoricheskaya i sotsial'no-obrazovatel'naya mysl'. 2017. 6-1, 165-172. [in Russian]

Vorontsova Yu A. (2016). Entropiya i negentropiya v kommunikatsii [Entropy and negentropy in communication] in Symbol of Science, 2-3, 54-58. [in Russian]

Zagidullina, M. V. (2012). Informatsionnoye obshchestvo v kontekste Net-myshleniya [Information Society in the Context of Net Thinking] in Bulletin of the Chelyabinsk State University, 63: 48-51. [in Russian]

Zaretskaya O.V. (2017). Komp'yuternaya i internet-zavisimost': analiz i sistematizatsiya podkhodov k probleme [Elektronnyy resurs] in Psychological Science and Education, psyedu.ru, 9, 2: 145-165 doi: 10.17759/psyedu.2017090213 [in Russian]

Zvezdina A. A. (2015). Gipertekstual'nost' sovremennogo myshleniya [Hypertextuality of modern thinking] in Bulletin of ISTU, 4, 99: 386-390. [in Russian] 